\title{
HILGARDI A
}

A Journal of Agricultural Science Published by the California Agricultural Experiment Station

\section{AN INTERSPECIFIC HYBRID IN ALLIUM}

S. L. EMSWELLER AND H. A. JONES

MEIOSIS IN ALLIUM FISTULOSUM, ALLIUM CEPA, AND THEIR HYBRID

S. L. EMSWELLER AND H. A. JONES 


\section{H}

A Journal of Agricultural Science Published by

the California Agricultural Experiment Station

Vow. 9

MARCH, 1935

No. 5

\section{AN INTERSPECIFIC HYBRID IN ALLIUM ${ }^{1}$}

S. L. EMSWELLER ${ }^{2}$ AND H. A. JONES 3

\section{INTRODUCTION}

Porter AND Jones, ${ }^{(5)}$ testing several varieties of Allium cepa $\mathrm{L}$. and other species of the same genus, found that the Nebuka, a type of A. fistulosum, was markedly resistant to pinkroot, caused by Phoma terrestris Hansen, and showed no indication of injury when grown continuously for several years in heavily infested soil. Felix ${ }^{(2)}$ has also reported that varieties of $A$. fistulosum, namely Winterhecke and White Welsh as well as different strains of Nebuka (Natsu-negi Nebuka, Sinju negi Nebuka, Tokyo-Nebuka, Itwatsuki), are resistant to pinkroot. In addition, he states that the different strains of Nebuka are highly resistant to smut, caused by Urocystis cepulae Frost: although under favorable conditions, infection frequently averaged 10 to 20 per cent in the cotyledon stage, it always fell to 0.5 per cent or less in later counts. Anderson ${ }^{(1)}$ also reports that the variety Winterhecke is resistant to smut. In a letter dated December 6, 1932, Professor A. G. Newhall of Cornell University states that seedlings from Nebuka seed grown at Davis, California, were practically immune to smut.

In a recent paper, Jones, Bailey, and Emsweller ${ }^{(4)}$ have shown that the Nebuka onion is also resistant to thrips, having a smaller number per plant than any other onion variety except White Persian, which it somewhat resembles in foliage characters, especially the circular leaves, spreading habit of growth, and long sheath region.

The various types of Allium fistulosum have little commercial importance in America; but their resistance to pinkroot, smut, and thrips would be very valuable characters to incorporate in any of the $A$. cepa

1 Received for publication October 22, 1934.

2 Assistant Professor of Truck Crops and Assistant Olericulturist in the Experiment Station.

3 Professor of Truck Crops and Olericulturist in the Experiment Station. 
varieties. With these objectives in view, crosses between the two species were made in the spring of 1931 . For the first cross a strain of Yellow Globe Danvers (pedigree, 15-108-1), inbred for two generations, was used as the female parent; and Nebuka (pedigree 37-1) was used as the male parent. Only 7 seeds were secured from several hundred hand pollinations, and these were planted as soon as mature. Although several

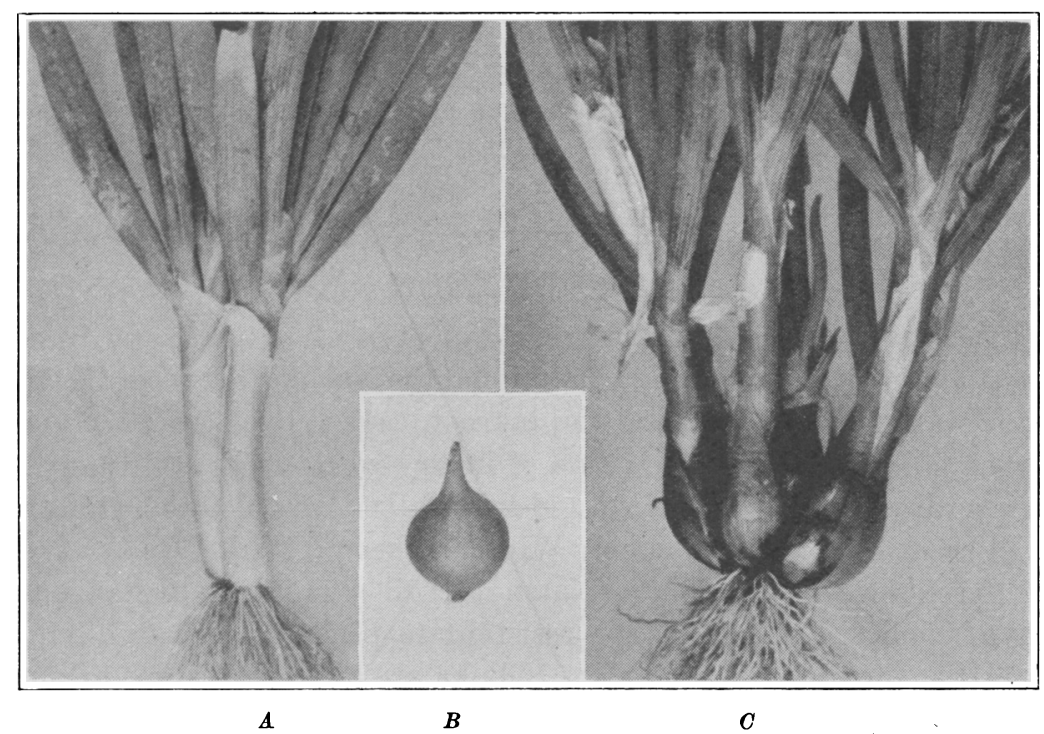

Fig. 1.-A, Allium fistulosum (type, Nebuka) ; B, Allium cepa, variety Yellow Globe Danvers, pedigree $15-108-1 ; C$, the $\mathrm{F}_{1}$ hybrid. Photographed September $9,1931$.

germinated, only 1 seedling survived. This grew very rapidly during the summer of 1931, forming a number of basal subdivisions (fig. 1), which were separated and replanted on September 9 .

A second cross was made in 1933 between the variety White Persian (Allium cepa) and Nebuka. From the 110 seeds secured, only 25 seedlings survived. The White Persian variety, obtained from Persia by the United States Department of Agriculture Division of Foreign Plant Introduction, has been described elsewhere. ${ }^{(4)}$ This hybrid was particularly interesting because of the ease with which a large number of seeds were secured and because of their precocious germination within the unripened ovary. While being removed from the ovary, many of the germinating seeds were killed by injury to the emerged radicle. This phenomenon was probably not caused by environmental conditions, for when other umbels of the same White Persian plant were selfed and open-pollinated, the seed behaved normally. Possibly Nebuka is more 
closely related to White Persian than to other commonly cultivated varieties; and, as stated above, the two resemble each other very closely in certain characters.

In the spring of 1934, flies were used to make crosses between Nebuka and Crystal White Wax, Yellow Bermuda, and several other cepa varieties. In the Crystal White Wax $\times$ Nebuka cross, 135 seeds were secured; in the Yellow Bermuda $\times$ Nebuka cross, 175 seeds. The seed set readily in both crosses. At present a large number of the hybrids are growing vigorously.

The hybrids mentioned above were secured by controlled pollinations, made either by hand or with flies. Hybrids between the two species have also been secured by planting adjacent cultures and collecting openpollinated seed. In 1932, Nebuka and Australian Brown were planted side by side. In 1933, 32 species hybrids were found among the plants grown from the Nebuka seed, on an area of about $1 / 16$ acre. They were recognized in the field by their vigor and semicircular leaves, which were typical of the hybrids produced under controlled conditions. The second year, the floral characters and sterility of these plants fully confirmed their hybrid nature. Ten of these hybrids were divided and planted to be used for further study and for backcrossing to each parent.

In 1933, Nebuka (Allium fistulosum), and California Early Red, (A. cepa, 21-22-1) were planted close together and open-pollinated seed was collected. In a population of 836 plants grown from seed of the Nebuka parent, 17 hybrids were found, whereas among approximately 5,000 plants grown from seed of the California Early Red parent, no hybrids appeared. Apparently, therefore, these species cross in the open. but more readily in one direction.

\section{BEHAVIOR OF THE HYBRID}

Thus far, hybrids between Nebuka and Yellow Globe Danvers, Australian Brown, White Persian, and California Early Red have been grown through their vegetative cycle, and the first three have also been carried through at least one season of flowering. As regards certain of the following characters, all behaved alike.

Bulbing.-The Nebuka types are nonbulbing and, as they grow at Davis, display no swelling at the base of the sheath region. The hybrids of Nebuka with Allium cepa are slightly bulbing (fig. 2).

Life Cycle.-Nebuka is a perennial type; although seed is produced in abundance, the plants continue to form divisions at the base, and these can be used for propagation. The varieties of Allium cepa are usually grown as biennials, a bulb being produced the first year and seed the second. The hybrids between the two are perennials; the tops remain 
erect, and the plants continue to grow as long as weather conditions are favorable. The single Yellow Globe Danvers $\times$ Nebuka hybrid originally secured has been increased by vegetative propagation until at present 208 plants are growing in the field. The other hybrid plants are also being increased by this method.

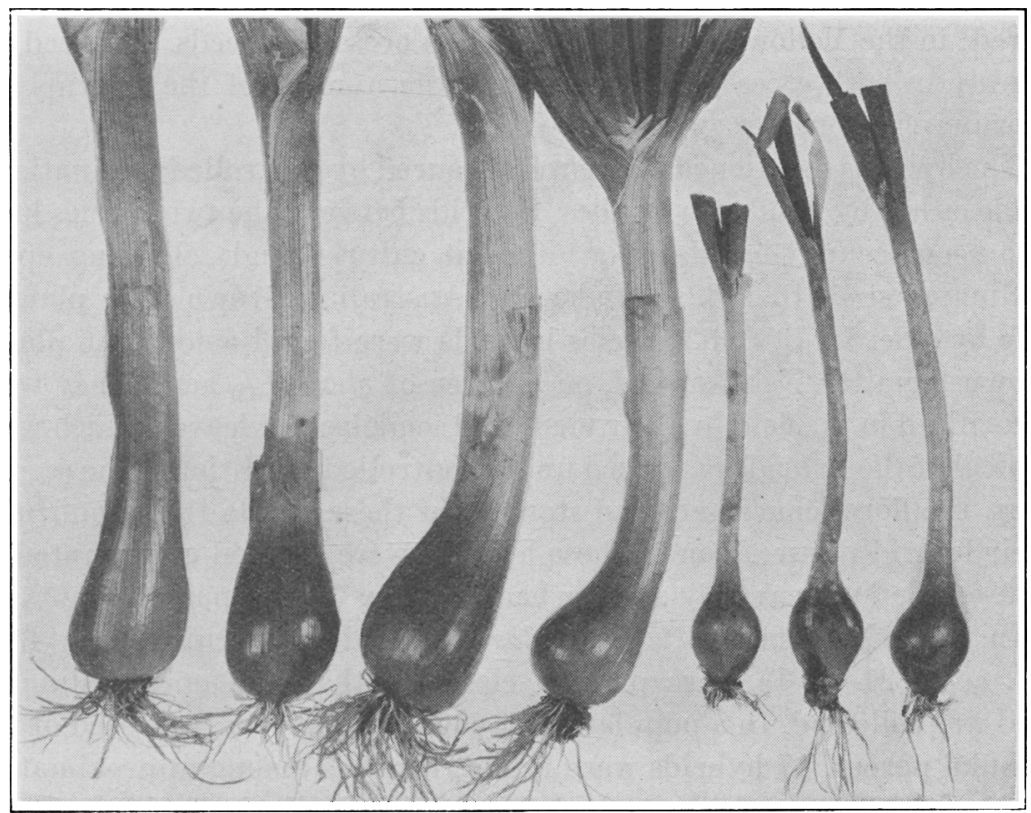

Fig. 2.-Hybrids of Yellow Globe Danvers (15-108-1) $\times$ Nebuka showing the extent of bulbing in the $F_{1}$. Photographed August 13, 1934.

Date of Flowering.-In the fall of 1931, the Yellow Globe Danvers $\times$ Nebuka hybrid and both parents were set side by side in the open field so that earliness of flowering and length of flowering period might be compared. The following spring the first Nebuka flowers were open on March 19, those of Yellow Globe Danvers on May 8, and those of the hybrid on April 10. Another comparison was made in 1933, when the first flowers of Nebuka, Yellow Globe Danvers, and the hybrid opened on March 12, May 14, and April 11, respectively. Nebuka flowers are always first to open, and Yellow Globe Danvers last, with the hybrid opening midway in time between the two parents. Nebuka usually begins to bloom early in March and, as a rule, continues until late July or early August; Yellow Globe Danvers has a much shorter flowering period beginning about the first of May and finishing early in July. The hybrid begins to bloom about a month after Nebuka and, as a rule, continues fully as long. 


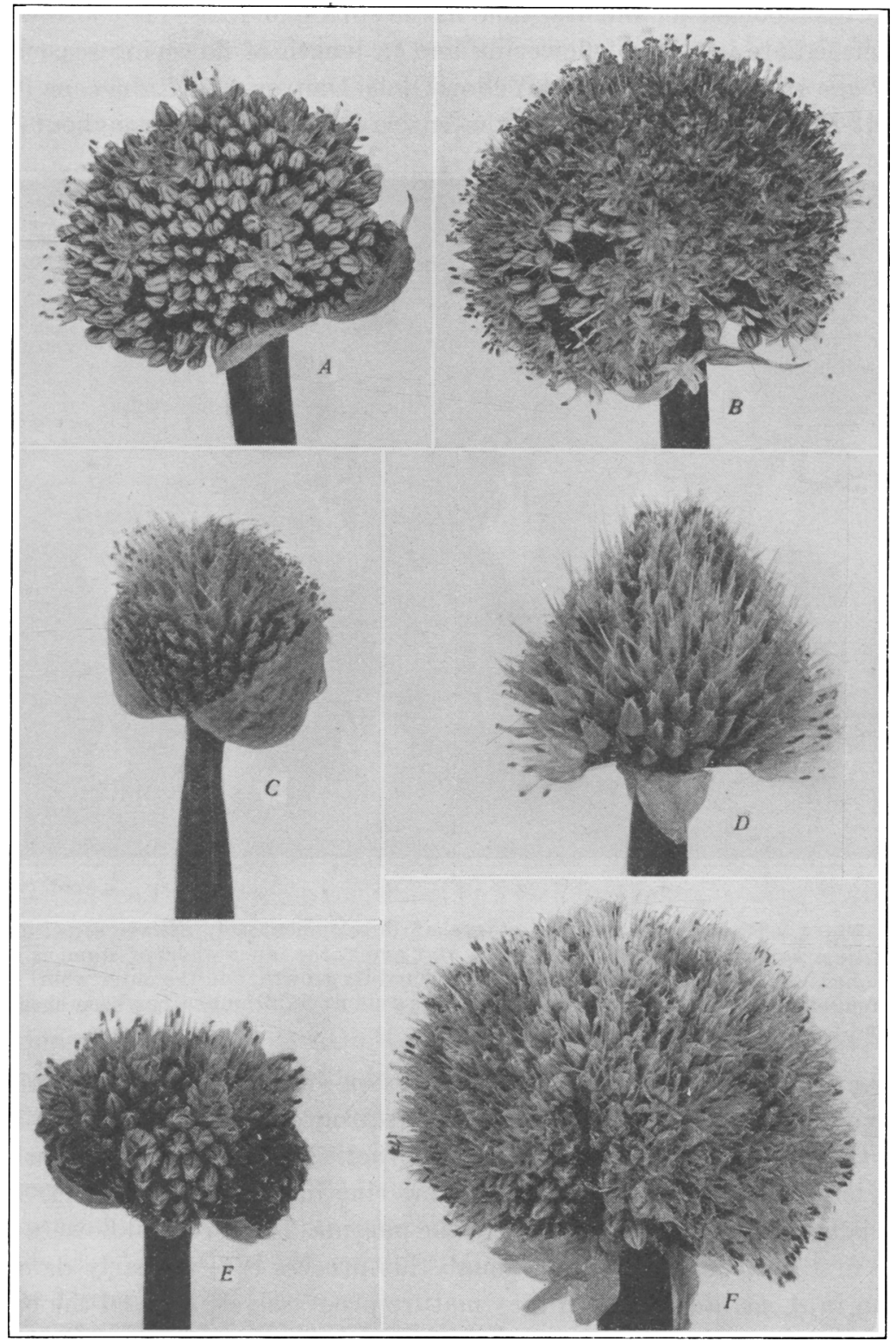

Fig. 3.--Early and late flowering stages: $A$ and $B$, Allium cepa; $C$ and $D$, Allium fistulosum; and $E$ and $F$, the cepa $\times$ fistulosum hybrid. 
The Nebuka $\times$ Australian Brown and the White Persian $\times$ Nebuka hybrids bloomed for the first time in the spring of 1934 . They also were intermediate in time of flowering and in length of flowering season.

Type of Inflorescence.-In Yellow Globe Danvers of Allium cepa (fig. $3 A, B)$ anthesis occurs over the entire inflorescence throughout the

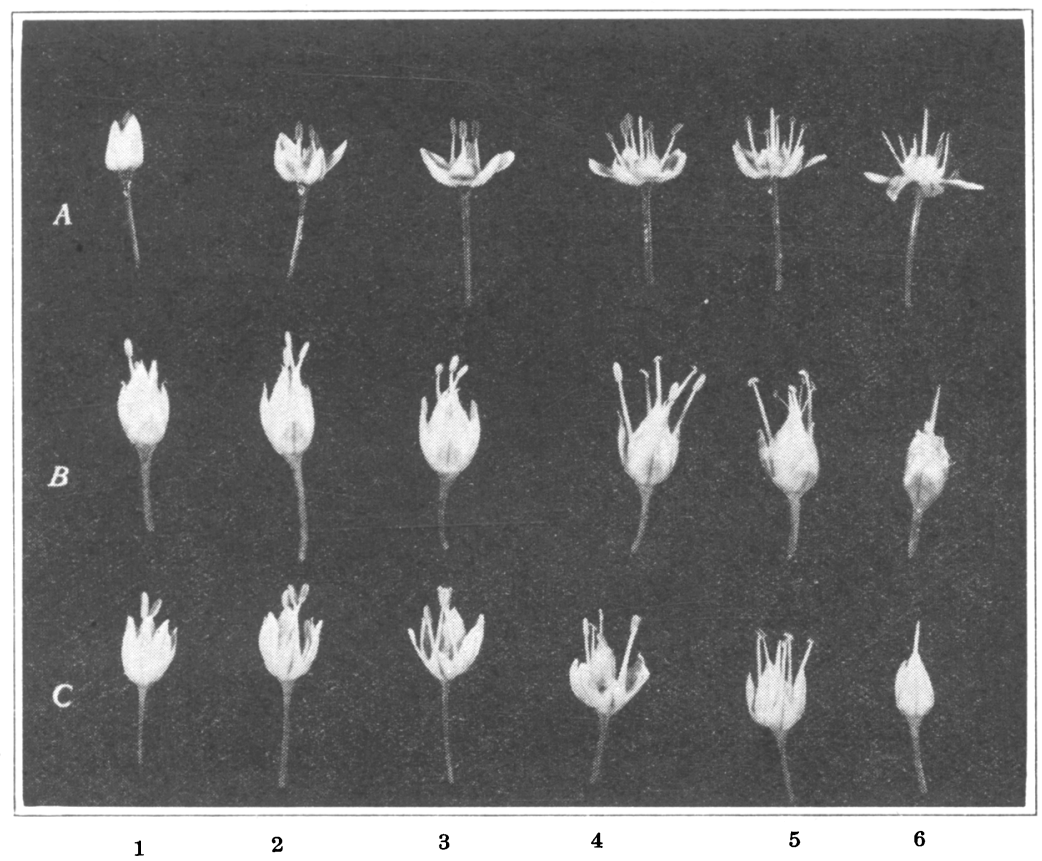

Fig. 4.-Flowers at different stages of development: $A$, Allium cepa; $B$, Allium fistulosum; and $C$, the hybrid. At 1 and $\mathscr{Z}$, the inner whorl of stamens is elongated; at 3, the inner whorl has completed its growth, and the outer whorl is elongating; 4, the inner whorl has shed its pollen; 5 , all pollen has been shed; and 6 , stigmas are receptive.

flowering period. In Nebuka, $A$. fistulosum (fig. $3 C, D$ ), the terminal flowers open first, and anthesis proceeds progressively toward the base. At the tip of the umbel, seed may be practically mature, while toward the base buds are just opening. In flowering habit the hybrid (fig. $3 E$, $\left.F^{\prime}\right)$ is intermediate between that of the parents. The terminal flowers are the first to open (fig. $3 E$ ) although this process is less clearly defined than in A. fistulosum; then they mature progressively toward the base. Thereafter, anthesis occurs over the entire inflorescence (fig. $3 F$ ), as is the habit of Yellow Globe Danvers and other varieties of $A$. cepa.

Flower Habit.-In Allium cepa the flower is fully expanded at anthesis. In $A$. fistulosum the perianth remains erect. In this character the hybrid resembles the fistulosum parent very closely (fig. 4). 
Fertility.-All the hybrids that have bloomed have been practically self-sterile, though several hundred inflorescences have been isolated under paper as well as cloth bags, with flies as pollinators. In the White Persian $X$ Nebuka hybrids three $\mathrm{F}_{2}$ seeds have been secured. Under open-pollinated conditions, however, five seeds were obtained in 1933 from a large group of the Yellow Globe Danvers $\times$ Nebuka hybrids. These are probably backcrosses to several Allium cepa varieties growing nearby. In 1934 they formed bulbs of various sizes, shapes, and colors. When the Yellow Globe Danvers $X$ Nebuka hybrid was used as the maternal parent in controlled backerosses, seed was never secured. This hybrid has, however, functioned as a pollen parent in backerosses to both A. cepa and A. fistulosum. Its behavior is rather unusual, for in most instances species hybrids have been more highly backcross fertile when used as the maternal parent. If only a small per cent of the gametes are functional, however, they probably occur more frequently in the sperm cells because of the very large number produced as compared with the egg cells. Since at least some of the eggs and pollen grains are functional, one might reasonably expect that under favorable conditions some $\mathrm{F}_{2}$ seed should be secured.

Resistance to Pinkroot and Smut.-The Yellow Globe Danvers $\times$ Nebuka and the Nebuka $X$ Australian Brown hybrids have been grown in the field on soil heavily infested with the pinkroot organism. Though the roots show some pink, the plants apparently are not checked in their growth. The variety Australian Brown has proved very susceptible to pinkroot; yet the hybrid grew vigorously on sick soil throughout the season. Even though some roots may be killed by the pinkroot organism, the plants are able, apparently, to supply new ones fast enough for good growth. The hybrids have thus far not been tested for smut resistance.

Leaf Shape.-In the Nebuka varieties the leaves are circular in cross section, whereas in Yellow Globe Danvers, Australian Brown, and California Early Red the leaf blade is semicircular. In the hybrid involving these varieties, the Allium cepa type of leaf is dominant. The White Persian, as noted above, has a leaf blade that is circular in cross section, closely resembling that of $A$. fistulosum. As expected, the leaf blade of the hybrid is similar, giving this cross a distinctive appearance.

Vigor.-Under similar conditions, the hybrids grow considerably taller than either of the parents.

Stability.-These hybrids, though practically sterile, are very vigorous and multiply rapidly by subdivisions at the base. Under natural conditions, they would probably be able to increase and perpetuate themselves. In this respect they resemble garlic (Allium sativum), a fully accepted species, which is completely sterile and reproduces en- 
tirely by division of the bulb. The widespread distribution of garlic has probably been accomplished by man because of its economic importance.

Backcrosses.-Fortunately the hybrids have proved somewhat fertile in backcrosses to both species, but only when used as the pollen parent. In 1933, backerosses were obtained to both Allium cepa and A. fistulosum; and backeross seedlings are now being grown. It is very likely that as backcrossing continues, fertility will increase, and it will be possible to secure a sufficiently large population to make selections for resistance to pinkroot and smut.

\section{ACKNOWLEDGMENTS}

The writers wish to acknowledge the assistance of Vedder Wright, James Welch, and Herbert Hiroshige in making some of the above crosses. 


\section{LITERATURE CITED}

1 Anderson, P. J.

1925. Comparative susceptibility of onion varieties and species of Allium to Urocystis cepulae. Jour Agr. Research 31:275-286.

2 FrLIX, E. L.

1933. Disease resistance in Allium fistulosum L. Phytopathology 23:109-110.

3 Jones, H. A., and S. L. EMsweller.

1933. Methods of breeding onions. Hilgardia 7(16):625-642.

4 Jones, H. A., S. F. Bailey, and S. L. Emsweller.

1934. Thrips resistance in the onion. Hilgardia 8(7):213-232.

5 Porter, D. R., and H. A. Jones.

1933. Resistance of some of the cultivated species of Allium to pinkroot (Phoma terrestris Hansen). Phytopathology 23:290-298. 